\title{
Habere Erişim Pratiklerinin Dönüşümü: Üniversite Öğrencileri Üzerine Bir Alan Araştırması ${ }^{1}$
}

\author{
DOI: 10.26466/opus.775977
}

\author{
* \\ Burak Somuncu* - Mustafa Temel ** \\ * Öğr. Gör., Adana Alparslan Türkeş Bilim ve Teknoloji Üniversitesi, Adana / Türkiye \\ E-Posta: bsomuncu@atu.edu.tr \\ ORCID: 0000-0002-0717-4017 \\ ** Dr. Öğr. Üyesi, Erciyes Üniversitesi İletişim Fakültesi, Kayseri/Türkiye \\ E-Posta: $\underline{\text { mustafatemel@erciyes.edu.tr }}$ \\ ORCID: $\underline{0000-0003-0828-0660}$
}

\begin{abstract}
Öz
Haberleşme insanların temel ihtiyaçları arasında yer almakta ve bu haberleşme ihtiyacı çeşitli araçlar vasıtasıyla karşılanmaktadır. Modern zamanda bireyler, habere erişim sürecinde medyayı temel başvuru kaynağı olarak tercih etmektedir. Geleneksel medya araçlarının sunmuş olduğu bu işlev, iletişim teknolojilerinin gelişmesi ile ortaya çıkan yeni medya araçları ile daha da güçlenmiş ve yeni medya araçları da haberleşme sürecinde aktif olarak kullanılır hale gelmiştir. Özellikle yeni medya araçlarının anlık erişim sağlayan etkileşimli yapısı sayesinde bireyler gazete, televizyon ve radyo gibi geleneksel medya araçlarına başvurmadan ya da bu araçların dijital platformdaki erişim bağlantılarını kullanarak habere ulaşabilmektedir. İnternet kullanım oranının artması da göz önüne alındığında, yeni medya araçlarının habere erişim sürecinde geleneksel medya araçlarına oranla daha aktif kullanilabildiğini gözlemlemek mümkündür. Bu alışkanlık, beraberinde medyanın temel çıktısı olan haberlerin tüketim şeklini de dönüştürebilecek bir durumu da beraberinde getirmektedir. Bu çalışmada da haberlere erişim pratiklerinin tespit edilmesi amaçlanmıştır. Bu bağlamda, haber alma sürecinde hangi iletişim araçlarının/kanallarının daha fazla tercih edildiğ i Adana ili örneğinde, üniversite öğrencilerinin katılımıyla tespit edilmeye çalışılmıştır. Adana Alparslan Türkeş Bilim ve Teknoloji Üniversitesi'nde eğitim gören üniversite öğrencileri arasından basit tesadüfi örnekleme yöntemi ile seçilen katılımcilara yönlendirilen anket soruları ile elde edilen veriler SPSS programı aracılığı ile işlenmiş, elde edilen veriler değerlendirilerek bireylerin habere ulaşma alş̧kanlıkları ölçülmüştür. Araştırma sonucunda katılımcıların büyük bir çoğunluğunun habere erişim sürecinde web sitelerini ve sosyal medya uygulamalarım kullandığ lenmiştir.
\end{abstract}

Anahtar Kelimeler: Haber, Geleneksel Medya, Yeni Medya, Habere Erişim, Sosyal Medya.

\footnotetext{
${ }^{1}$ Bu çalışma, 22-23 Şubat 2020 tarihinde "1.Uluslararası 'Yeni Dünyada iletişim' Kongresi'nde" sunulmuş olan "Habere Erişim Pratiklerinin Tespiti: Üniversite Öğrencileri Üzerine Bir İnceleme" başlıklı bildirinin genişletilmiş ve yeniden revize edilmiş halidir.
} 


\title{
Transformation Of News Access Practices: A Field Research On University Students
}

\begin{abstract}
Communication is among the basic needs of people and this communication need is carried out through various means. In the modern time, individuals prefer the media as the main source of reference in accessing the news. This function offered by traditional media tools have gained further strength with the new media tools that have occurred with the development of communication technologies and the new media tools have become actively useable in the process of communication. Particularly due to the interactive structure of new media tools that provide instant access; individuals can access the news without resorting to traditional media tools such as newspapers, television and radio or by using the access links of these tools on the digital platform. Considering the increase in the internet usage rate, it is possible to observe that new media tools can be used more actively than the traditional media tools in the process of accessing the news. This habit brings along a situation that may transform the way of consuming the news/information, which are the main outputs of the media. It is aimed to determine the practices of access to the news in this study. In this context, it was tried to be determined which communication tools /channels are preferred more in the process of receiving the news in the example of Adana province with the participation of university students. The data obtained with the survey questions addressed to the participants chosen with the method of simple random sampling among the university students studying at Adana Alparslan Türkeş Univeristy of Science and Technology were processed through SPSS program, the data obtained were evaluated and the habits of individuals in reaching the news were measured. As a result of the research, it was determined that the majority of the participants used websites and social media applications in accessing the news.
\end{abstract}

Keywords: News, Traditional Media, New Media, Access to the News, Social Media 


\section{Giriş}

İletişim teknolojileri bireylerin gündelik hayat pratiklerini önemli ölçüde etkileyen ve dönüştüren bir yapıya sahiptir. Bireylerin dijital araçlara bu yönelimi, birçok alışkanlıkların dönüşümüne sebep olmuş ve bireylerin habere erişme pratikleri de bu süreçte değişmiştir. Başta internet olmak üzere, web 2.0 teknolojisinin gelişimi ile kullanımı artan ve etkileşime imkan tanıyan yapısı sebebiyle hayatın vazgeçilmez araçları haline gelen sosyal medya² uygulamaları/araçları, bireylerin habere erişim sürecinde aktif kullanılır olmuş ve bu süreçte dijital ortamlar bilgiye/habere erişimde ${ }^{3}$ en fazla kullanılan araçlar haline gelmiştir.

Yapılan araştırmalar da, zaman içerisinde bireylerin habere erişim pratiklerinin geleneksel iletişim araçlarından internet, yeni medya gibi dijital araçlara doğru yön değiştirdiğini göstermektedir. 2003 yılında yapılan bir araştırmaya göre, internet kullanıcıları artık interneti haber almada radyo-televizyon ve gazete kadar etkin olarak kullanmaktadır. İnternet kullanıcıları, habere istedikleri anda ulaşabildikleri, gazete/radyo ve televizyonlarda olmayan haberleri internetten temin edebildikleri, farklı kaynaklara erişim sağladıkları için internetten haber almaya başlamıştır. Okurlar, özellikle de hızlı ve anında ulaşabildikleri için haber alma ihtiyaçlarını internetten karşılamaktadır (Karaduman, 2003, s. 7-8). 2008 yılında yapılan bir diğer araştırmaya göre, öğrencilerin önemli bir kısmı gazeteyi her gün düzenli olarak, üstelik bayiden satın alarak okumaktadır. Gazete en çok haber/bilgilenme amacıyla satın alınmaktadır. Yine araştırmada internetin öğrenciler tarafından haber elde etme amacıyla kullanıldığı belirlenmiştir (Toruk, 2008, s. 487). Kutlu, Bekiroğlu ve Öztürk'ün 2009 yılında üniversite öğrencileri üzerine yapmış olduğu araştırmada habere erişim pratiklerinin değiştiğini göstermektedir. Anadolu Üniversitesi İletişim Bilimleri Fakültesi'nde okuyan öğrencilerin haber alma alışkanlıklarını ortaya koymayı amaçlayan çalışmada, haber alma

\footnotetext{
${ }^{2}$ We are social ve Hootsuit tarafından yayınlanan 2019 yılı istatistiki verilerine göre, Türkiye'de 59.36 milyon internet kullanıcısı, 52 milyon aktif sosyal medya kullanıcısı, 44 milyon aktif mobil sosyal medya kullanıcısı bulunmaktadır. Yine araştırmaya göre, bireylerin internette günde ortalama 7 saat zaman geçirdikleri; günde ortalama 2 saat 46 dakika sosyal medya araçlarını kullandıkları belirtilmektedir (www.dijilopedi.com; www.wearesocial.com).

${ }^{3}$ Araştırmalara göre; bireyler, özellikle de öğrenciler, interneti ve diğer yeni iletişim teknolojilerini bilgi arama, bilgi edinme ve araştırma/öğrenme motivasyonları ile kullanmaktadır (Eken ve Aydın, 2018, s. 894; Balcı ve Ayhan, 2007, s. 178-180).
} 
ihtiyacının karşılanması noktasında en çok başvurulan kitle iletişim araçlarının sirasiyla televizyon, internet, gazete, radyo ve dergi olduğu belirlenmiştir. İnternetin, gazete, radyo ve dergiden daha fazla tercih edildiği ortaya çımıştır (Kutlu, Bekiroğlu ve Öztürk, 2009, s. 186-187). 2015 yılında yapılan bir diğer araştırmada da yeni medya araçlarının habere erişim sürecinde kullanılmaya başlandığı tespit edilmiştir. Araştırma sonuçlarına göre bireyler internet gazeteciliği şeklinde veya sosyal medya araçları ile habere erişimi daha fazla tercih etmektedir (Taşdemir, 2015, s. 112).

Görülebileceği üzere, bireylerin haberleri keşfetme ve tüketme biçimleri değişikliğe uğramıştır. Bu çalışmada da; habere erişim pratiklerinin dönüşümünün tespit edilmesi, habere erişim sürecinde sık kullanılan iletişim araçlarının belirlenmesi amaçlanmıştır. Literatürdeki çalışmalara ek olarak, dijital haber mecralarının kullanım farklılıklarına da odaklanan çalışmada bireylerin yeni medyada yoğunlaşan haber tüketim pratikleri incelenmiştir. Bu bağlamda, dijitalleşmenin bilgi edinme/haberleşme sürecindeki rolüne odaklanan çalışmada, iletişim teknolojileri ve habere erişim süreci ilişkiselliği ile ilgili teorik bir değerlendirme yaptıktan sonra, Adana Alparslan Türkeş Bilim ve Teknoloji Üniversitesi'nde eğitim gören öğrenciler arasından basit tesadüfü örnekleme yöntemi ile seçilen 200 katılımcıya uygulanan ankete ilişkin bulgulara yer verilmiştir.

\section{İletişim Teknolojileri ve Habere Erişim Pratikleri}

İnternet ve yeni medya teknolojilerinin kişilerin hayatına girmesi ile birlikte iletişim, gazetecilik ve haber alanında değişimler ve dönüşümler meydana gelmiştir. Yeni medya, gazeteciliğin basılı yayıncılıktan ziyade dijital platformda yeniden bir biçim kazanması yönünde bir anlayışı doğurmuştur (Sucu, 2020, s. 41). Yine bu değişimle birlikte, basılı gazete okuyucusunun 'geleneksel okuyucu', radyo dinleyicisinin 'nostaljik ve sadık dinleyici' olarak nitelendirildiği günümüzde artık; internet ve bilgisayar teknolojisinin bütün olanaklarından (online gazete, video görüntü, web-tv gibi) yararlanan yeni medya takipçisini yarattı̆̆ farklı bir kitle söz konusudur. Aynı zamanda, her geçen gün gelişmekte olan bir sektör olarak medya; bu yeni ve farklı kitleye hitap edebilmek için kendini ve çalışanlarını bu değişimin dışında tutamamaktadır (Kutlu, Bekiroğlu ve Öztürk, 2009, s. 178). 
Bilgi ve iletişim teknolojisindeki bu gelişmelerle birlikte habere erişim pratiklerinde yaşanan değişikliklerin iki nedenden kaynaklandığını söylemek mümkündür. Illki, haber/bilgi üretim ortamındaki teknolojik ve yapısal değişimler, ikincisi ise elde edilen verileri tüketenlerin tüketim pratiklerinde farklılaşan eğilimlerdir (Aktaran Karaaslan, 2018, s. 248).

\section{Teknolojik ve Yapısal Değişimler}

İletişim teknolojilerindeki yenilikler, enformasyonun iletişim araçlarındaki dolaşımını etkilemiştir. Bu sebeple, günümüzde geleneksel iletişim araçlarının gelişmeleri kamuoyuna aktarma noktasında yetersiz kalması ve hızlı bir şekilde okuyucuya ulaştıramaması haberciliğin de online ortamlara taşınmasını beraberinde getirmiştir (Değirmencioğlu, 2016a, s. 57). A $\breve{g}$ tabanlı yeni medya, interaktif olabilme, talep üzerine uyarlanabilme; metin, görüntü, hareket eden resimler ve sesin yeni kombinasyonların bir araya getirebilme; yeni toplumlar oluşturabilme (değişim sürecinde etkin olma); diğer medyalarda mümkün olmayacak bir şekilde muhabirliğe ilişkin derinlik sağlama, dokuyu ve bağlamı sunmak için sınırsız alana sahip olabilme gibi özellikleri sebebiyle bu süreçte gazetecilik pratiklerinin değişmesini sağlamıştır (Pavlik, 2013, s. 48).

Yeni medya; birçok medya sistemini (çok ortamlılık/multimedya), veri taşıma sistemini bünyesinde barındıran; hiper-metin sağlayan yapısı, geleneksel medyadaki 'aynı anda'lık gerekliliğini ortadan kaldırabilen eş zamanlı ve eş zamansız olarak etkileşime imkân sağlayan özelliği; kitlesizleştirme gibi özellikleri ve geleneksel medya vb. platformlardaki tek yönlü iletişimi hedef kitleyle karşılıklı etkileşim haline çeviren özellikleriyle ön plana çıkmaktadır. Örneğin, yeni medya platformlarından biri olan elektronik posta aracllı̆̆ıyla bilgisayar ağlarında kullanıcılar birbirleriyle yazılı olarak eşzamanlı ya da eşzamansız olarak haberleşebilmektedirler. Bu yönde oluşturulan bilgisayar ağları; kişilerin haberleşme isteklerini hızlı ve güvenli bir şekilde karşılayabilmektedir. Kitle yerine bireyi ve bireyin tercihlerini ön plana çıkaran yeni medyada kaynak ile hedef arasındaki tek yönlü iletişimin yerine kaynak ve hedefin bireyde toplanabildiği, 'anında'lığın ön plana çıktığı çift yönlü bir iletişim süreci söz konusu olmaktadır (Gülnar ve Balcı, 2011, s. 69-77; Sucu, 2020, s. 51). 
Yaşanan bu dijital dönüşüm, gazetelerin dijital ortamlarda yer edinmesini zorunlu hale getirmiştir. Günümüzde neredeyse bütün gazeteler artık kendi hizmet sağlayıcıları üzerinden oluşturdukları özgün dijital gazeteleri internet üzerinden kullanıcılara sunmaktadır. Dijital teknoloji sadece haber sunum kanallarını değiştirmekle kalmamış, habercilik anlayışında da değişimlere sebep olmuştur. Yeni medya ile her geçen gün habercilikle ilgili yeni ve farklı kavramlar ortaya çımış; haberin bulunması, işlenmesi ve dağıtılması da önemli ölçüde değişime uğramıştır (Karatoprak, 2019, s. 77; Pavlik, 2013, s. 75).

Online gazetecilik olarak adlandırılan bu süreçte, geleneksel iletişim araçları tarafından üretilen yazıll, sesli ve görüntülü her türlü enformasyon artık dijital alt yapı sayesinde bir arada sunulabilir olmuştur (Değirmencioğlu, 2016b, s. 593-594). Yine, online gazeteciliğin güncelleme, depolama ve arşiv olanakları, kullanıcıyla etkileşim olanağı (geri bildirim-sohbet), çoklu ortam, multimedya ayrıcalığı, hiper-metinden yararlanma imkanı, erişim sürecinde kişisellik sunması (Halıc1, 2005, s. 156-162) geleneksel gazeteciliğin etkisinin azalmasına sebep olmuştur. Geleneksel gazeteciliğin etkisini azaltan internet gazeteciliğinin sunmuş olduğu imkânları şu şekilde sıralamak mümkündür (Çakır, 2007, s. 140):

- Haberi çok hızlı bir biçimde verebilmesi ve haberin sürekli güncellenebilmesi.

- Okurun habere 24 saat, dilediği zaman ulaşabilmesi.

- Multimedya temelinde ses-grafik-görüntülü dosyaları kullanılabilmesi.

- Arşivdeki haberlere kolayca ulaşılabilmesi ve istenilen haberlerin saklanabilmesi.

- Okurla interaktif etkileşim sağlaması; okurun yorumlarını anında iletebilmesi.

- Haberle ilgili konularda, web sitelerinin linklerinin verilmesiyle, arka plan bilgilerine kolaylıkla ulaşılabilmesi.

- Diğer medyada yer almayan farklı haberleri bulabilme imkânının olması.

- Okurun haber oluşumuna doğrudan etki edebilmesi.

Teknik alt yapı ve sağladığı bu imkânlar ile güçlenen internet gazeteciliği, sosyal medya araçlarının gelişmesi ile birlikte habere ulaşımı ve haberin yayılımını kolaylaştırmış, sosyal medya mecralarının interaktif özelliğiyle okuyucunun/dinleyicinin/izleyicinin de haber üretim sürecine dâhil olmasını daha da güçlendirmiştir. İnternet üzerinden bir platform kurabilmenin ucuza 
mal edilebilmesi, gazetecilerin veya bireylerin bir medya organı gibi kendi yayınını yapabilmesini sağlamış ve alternatif dijital medya alanları oluşmaya başlamıştır. Bu ortamın hızla şekillenmesini ise mobil teknolojilerin ilerlemesi sağlamıştır. Artık akıllı bir telefonla tüm dünyaya eş zamanlı yayın yapmak, internet ağları ve yeni medya sayesinde mümkün hale gelmiştir (Karatoprak, 2019, s. 60). Bu süreçte özellikle gündelik yaşamda oldukça önemli bir yere sahip olan tablet bilgisayarlar ve akıllı cep telefonları, geleneksel iletişim araçlarından ziyade yaygin olarak kullanılan iletişim araçları olmuştur. Geleneksel medya kuruluşları da bu yaşam biçimlerine uyum sağlayabilmek için haber üretim, sunum ve yayım pratiklerini değiştirmişler; dijital ortamlara uyumlu içerikler oluşturmaya başlamışlardır (Değirmencioğlu, 2016a, s. 57).

\section{Tüketim Pratiklerindeki Değişimler}

Dijital ortamların özellikle kolay/hızlı erişebilme, görsel/işitsel ve yazılı içeriklere bir arada yer verme ve farklı kaynaklara ulaşabilme gibi sahip olduğu alt yapı sayesinde bireyler geleneksel gazeteler yerine dijital ortamlara yönelmeye başlamıştır. Günümüzde daha fazla habere ulaşmak ve ulaştıkları haberleri paylaşma arzusuna sahip olan bireyler (Comscore, 2019, s. 3), sadece gazetenin sunduğu içerikle sınırlı kalmayıp, etkileşim içinde olabildiği platformları tercih etmektedir. Farklı haberlere ve kaynaklara erişim sağlamak isteyen okurlar, dijital medya sayesinde hem haber üretebilmekte hem de haberleri takip edebilmektedir. Bu sayede pasif konumundan uzaklaşan okurlar, online mecralar ile haber üretim sürecinde aktif rol oynayabilmektedir (Karaaslan, 2018, s. 248).

İnternet, okurlara hem 'en hizlısını', hem de 'daha fazlasını' sunmaktadır. Habere ulaşabilmek için televizyonun haber bültenini ya da ertesi gün bas1lacak gazeteyi bekleyen okur, artık günün 24 saatinde dilediği habere, dilediği kaynaktan ulaşabilmektedir (Karaduman, 2003, s. 2). Yapılan araştırmalarda da, dijital çağda haberlere online ortamlarda doğrudan ya da arama motorları aracılığıyla erişimin tercih edildiği belirlenmiştir. Özellikle Z kuşağının ${ }^{4}$ büyük bir kısmının haber kaynağını sosyal medya oluşturmaktadır.

\footnotetext{
${ }^{4}$ Habere erişim pratiklerinin yaş grubuna göre değiştiğini, özellikle genç yetişkinlerle orta yaş grubu arasında haber tüketim biçimlerinin farklılık gösterdiğini söylemek mümkündür. Fakat süreç içerisinde teknoloji okuryazarlığının artmasıyla birlikte, yetişkinler ile gençler arasındaki haber ve bilgiye ulaşma yöntemleri benzerlik gösterecektir (Karaaslan, 2018, s. 257).
} 
Ayrıca kullanıcıların büyük bir kısmının online ortamlardaki içerikler için ödeme yapmaması da bireylerin habere erişim sürecinde bu araçları tercih etmesine sebep olmaktadır (Comscore, 2019, s. 4, 12).

Görülebileceği üzere, bireylerin haberleri keşfetme ve tüketme biçimleri değişikliğe uğramış, yeni medya araçları haberi tüketme amacıyla sık kullanır hale gelmişlerdir. Bu bakımdan günümüzde bireyler haber alma ihtiyaçların dijital ortam olan Facebook, Twitter, YouTube vb. gibi sosyal medya araçları üzerinden karşılamaktadırlar. Özellikle Twitter, güncel, kısa ve anlık paylaşımlara olanak sağlayan bir altyapıya sahip olmasından dolayı önemli alternatif bir haber ortamı olarak kullanılmaktadır. Bu sebeple, bireyler basılı gazete satın almaktan ziyade, sosyal medya hesapları üzerinden güvendikleri gazetelerin ya da medya kuruluşlarının Twitter sayfalarından haberlere ulaşmayı tercih etmektedirler. Ayrıca ulusal ve yerel medya kuruluşları da sosyal medya hesapları aracılığıyla haberlerini okuyucularına ve izleyicilerine aktarma ve dünya gündemine sunma olanağını elde etmektedirler (Sucu, 2020, s. 58; Kürkçü, 2016, s. 98).

Ayrıca, iletişim teknolojilerinin habere erişim pratiklerinde aktif kullanılması bazı problemlere de sebep olabilmektedir. Sosyal medya ortamları, habercilikte bir alternatif oluştururken bu mecraların haber kaynağı olarak kullanılması güvenilirlik problemini ortaya çıkarmaktadır (Güz, Yegen ve Yanık, 2017 , s. 1413). Sosyal medyanın hızlı enformasyon akışı sağlayan yapısından dolayı haber ve bilgi yayma konusunda geleneksel medyanın eşik bekçiliği rolü zayıflamış, bu durum belirli bir eşik bekçisinden geçen geleneksel medya içeriklerine oranla, sosyal medyada yanlış veya yanıltıcı haber içeriklerinin yayılmasını beraberinde getirmiştir (Kürkçü, 2016, s. 89). Online ortamlarda denetimsiz bir şekilde isteyen herkesin içerik üretme imkanına sahip olmasından dolayı sosyal medya araçlarında; manipülasyon, algı üretimi, bilginin doğruluğu/güvenilirliği gibi etik sorunlar; bilgiye/habere erişim sürecinde dijital araçların sık kullanılmasından dolayı geleneksel bilgi edinme çabasının zayıflaması, bilginin doğruluğunun teyit edil/e/memesi ve eksik/yanlış bilgilere maruz kalma problemleri ortaya çıkmıştır.

\section{Araştırmanın Tasarımı}

İnsanların en temel ihtiyaçları arasında yer alan haberleşme günümüzde iletişim teknolojilerinin aktif bir şekilde kullanılması ile mümkün olmaktadır. 
$\mathrm{Bu}$ durum neticesinde de teknolojinin gelişmesine paralel olarak, bilgi edinme, haberleşme yöntemleri de değişikliğe uğramaktadır. Dolayısıyla bu çalışmada da bireylerin haberleşme sürecinde başvurduğu yöntemler irdelenmiştir. Bu bağlamda araştırmada habere erişim pratiklerinin dönüşümünün tespit edilmesi; habere erişim sürecinde kullanılan iletişim teknolojilerinin belirlenmesi, dijital haber mecralarının kullanım farklılıklarının ortaya çıkarılması amaçlanmıştır.

\section{Araştırma Soruları}

Çalışma kapsamında aşağıdaki temel araştırma sorularının cevabı aranmıştır:

- Haber elde etme/bilgilenme sürecinde hangi iletişim araçları kullanılmaktadır?

- Haberlere online ortamda nasıl erişim sağlanmaktadır?

- Haberlere ulaşma ve bilgi edinme sürecinde tercih edilen iletişim araçlarının belirlenmesindeki temel etmenler nelerdir?

- Habere ulaşma sürecinde sosyal medya araçları neden tercih edilmektedir?

- Sosyal medya uygulamaları ile haber elde etme/bilgilenme sürecinde hangi teknolojik araçtan faydalanılmaktadır?

- Haber elde etme sürecinde gazetelere erişim şekli nasıldır?

\section{Araştırmanın Yöntemi ve Örneklem Seçimi}

Üniversite öğrencilerinin habere erişim pratiklerini tespit etmek amaciyla Adana Alparslan Türkeş Bilim ve Teknoloji Üniversitesi öğrencileri üzerinde bir saha araştırması gerçekleştirilmiştir. Araştırmanın evreni, Adana Alparslan Türkeş Bilim ve Teknoloji Üniversitesi lisans öğrencilerinden oluşmaktadır. Tesadüfï örneklem yoluyla seçilen 200 öğrenciye, elektronik ortam aracllığ 1 ile 13 sorudan oluşan anket formu yöneltilmiştir.

Araştırma örnekleminin belirlenme işlemi \%5 hata payı dikkate alınarak yapılmıştır (Yazıcıŏlu ve Erdoğan, 2004, s.50). 2019-2020 verilerine göre Adana Alparslan Türkeş Bilim ve Teknoloji Üniversitesi'nde 2216 lisans öğrencisi öğrenim görmektedir. Bu doğrultuda \%5 hata payı dikkate alınarak 200 öğrenci örneklem olarak belirlenmiştir. 
Anket formu iki kısımdan oluşmaktadır. Anket formunun ilk bölümünde, öğrencilerin demografik bilgilerine yer veren ve iletişim teknolojilerini kullanma alışkanlıklarını ölçen sorular yer almaktadır. Soru formunun ikinci bölümünde ise araştırma sorularından hareketle, habere erişim sürecinde kullanılan araçlar ve yöntemlerle birlikte bu süreçte kullanılan araçların tercih edilme sebepleri ile ilgili sorulara yer verilmiştir.

Son olarak, elde edilen veriler SPSS programı aracılığı ile işlenmiş ve bulgular değerlendirilerek bireylerin, üniversite öğrencileri özelinde, habere ulaşma alışkanlıkları belirtilmiştir.

\section{Bulgular}

\section{Demografik Özellikler}

Tablo 1. Demografik Bilgiler

\begin{tabular}{lll}
\hline Cinsiyet & Sayı & Yüzde \\
\hline Erkek & 97 & 48,5 \\
\hline Kadın & 87 & 43,5 \\
\hline Kayıp Değer & 16 & 8,0 \\
\hline Toplam & $\mathbf{2 0 0}$ & $\mathbf{1 0 0 , 0}$ \\
\hline
\end{tabular}

Tablo 1'deki verilere göre araştırmaya katılan öğrencilerin büyük çoğunluğunu erkekler oluşturmaktadır. 200 katılımcı içerisinde 97 (\%48,5) erkek, 87 $(\% 43,5)$ kadın öğrenci yer almaktadır.

\section{İletişim Araçların Kullanma Alışkanlıkları}

Araştırmanın bu bölümünde; geleneksel iletişim araçlarını ve sosyal medya uygulamaların kullanma sıklıkları ve bu araçların tercih edilme sebepleri sorgulanmiştır.

Tablo 2. Kitle İletişim Araçlarının Kullanım Sıklıklan

\begin{tabular}{lllllllll}
$\begin{array}{l}\text { Kitle } \\
\text { İletişim Araçları }\end{array}$ & \multicolumn{3}{l}{ Televizyon } & Gazete & & Radyo & & \multicolumn{2}{l}{$\begin{array}{l}\text { Internet/Sosyal } \\
\text { Medya } \\
\text { Uygulamaları }\end{array}$} \\
\hline Kullanım Sıklığı & Sayı & Yüzde & Sayı & Yüzde & Sayı & Yüzde & Sayı & Yüzde \\
\hline Hiç & 37 & 18,5 & 62 & 31,0 & 76 & 38,0 & - & - \\
\hline Çok Nadir & 61 & 30,5 & 76 & 38,0 & 55 & 27,5 & - & - \\
\hline Bazen & 63 & 31,5 & 46 & 23,0 & 45 & 22,5 & 5 & 2,5 \\
\hline Çoğu Zaman & 26 & 13,0 & 6 & 3,0 & 20 & 10,0 & 61 & 30,5 \\
\hline Her Zaman & 13 & 6,5 & 10 & 5,0 & 4 & 2,0 & 134 & 67,0 \\
\hline Toplam & $\mathbf{2 0 0}$ & $\mathbf{1 0 0 , 0}$ & $\mathbf{2 0 0}$ & $\mathbf{1 0 0 , 0}$ & $\mathbf{2 0 0}$ & $\mathbf{1 0 0 , 0}$ & $\mathbf{2 0 0}$ & $\mathbf{1 0 0 , 0}$ \\
\hline
\end{tabular}


Katılımcların kitle iletişim araçlarını kullanım sıklığının ölçüldüğü soruda; öğrencilerin en fazla internet/sosyal medya uygulamalarını kullandığı; internet/sosyal medya uygulamalarını kullanmayan hiç kimsenin olmadığ1 belirlenmiştir. Tablo 2'ye göre $134(\% 67,0)$ öğrenci, internet/sosyal medya araçlarını her zaman kullandığını ifade etmiştir. Ayrıca, geleneksel medya araçlarından televizyon, gazete ve radyonun kullanım sıklı̆̆ının düşük olduğu, hatta gazete ve radyo gibi iletişim araçlarının genellikle hiç tercih edilmediği ortaya çıkmıştır.

Tablo 3. Sosyal Medya Uygulamalarm Kullanım Sebepleri

\begin{tabular}{|c|c|c|c|c|c|c|c|c|c|c|c|c|c|c|}
\hline \multirow{2}{*}{$\begin{array}{l}\text { Kullanım } \\
\text { Sebepleri }\end{array}$} & \multicolumn{2}{|c|}{ 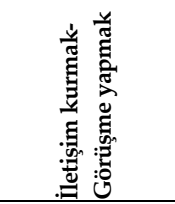 } & \multicolumn{2}{|c|}{ 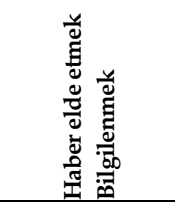 } & \multicolumn{2}{|c|}{ 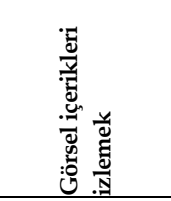 } & \multicolumn{2}{|c|}{ 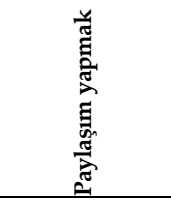 } & \multicolumn{2}{|c|}{ 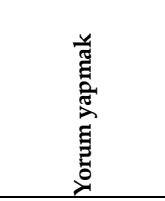 } & \multicolumn{2}{|c|}{ 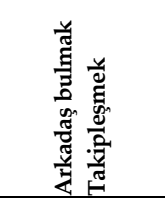 } & \multicolumn{2}{|c|}{ 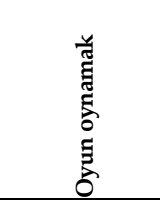 } \\
\hline & Sayı & Yüzde & Sayı & Yüzde & Sayı & Yüzde & Sayı & Yüzde & Sayı & Yüzde & Sayı & Yüzde & Sayı & Yüzde \\
\hline Hiç & 4 & 2,0 & - & - & - & - & 26 & 13,0 & 62 & 31,0 & 84 & 42,0 & 61 & 30,5 \\
\hline Çok Nadir & 15 & 7,5 & - & - & 9 & 4,5 & 70 & 35,0 & 76 & 38,0 & 39 & 19,5 & 38 & 19,0 \\
\hline Bazen & 25 & 12,5 & 26 & 13,0 & 25 & 12,5 & 48 & 24,0 & 29 & 14,5 & 40 & 20,0 & 37 & 18,5 \\
\hline Çoğu Zaman & 90 & 45,0 & 77 & 38,5 & 85 & 42,5 & 29 & 14,5 & 19 & 9,5 & 24 & 12,0 & 37 & 18,5 \\
\hline Her Zaman & 66 & 33,0 & 97 & 48,5 & 81 & 40,5 & 27 & 13,5 & 14 & 7,0 & 13 & 6,5 & 27 & 13,5 \\
\hline Toplam & 200 & 100,0 & 200 & 100,0 & 200 & 100,0 & 200 & 100,0 & 200 & 100,0 & 200 & 100,0 & 200 & 100,0 \\
\hline
\end{tabular}

Tablo 2'den elde edilen verilerden hareketle, katılımcıların günümüzde internet/sosyal medya araçlarını diğer iletişim araçlarına oranla daha fazla tercih ettiğini söylemek mümkündür. Bu gözlemden hareketle, sosyal medya araçlarının kullanım sebeplerinin ölçüldüğü soruda; Tablo 3'de görüleceği üzere, katılımcıların sosyal medya araçlarını çoğunlukla iletişim kurmak/görüşme yapmak ve haber elde etmek/bilgilenmek amacıyla kullandığı tespit edilmiştir. Özellikle haber elde etmek/bilgilenmek sosyal medya araçlarının tercih edilme sebepleri arasında üst sıradadır. Katılımcların tamamını sosyal medya araçlarını haber elde etme/bilgilenme sürecinde aktif olarak kullandıkları belirlenmiştir. 
Tablo 4. Sosyal Medya Uygulamalarını Kullanım Sıklığı

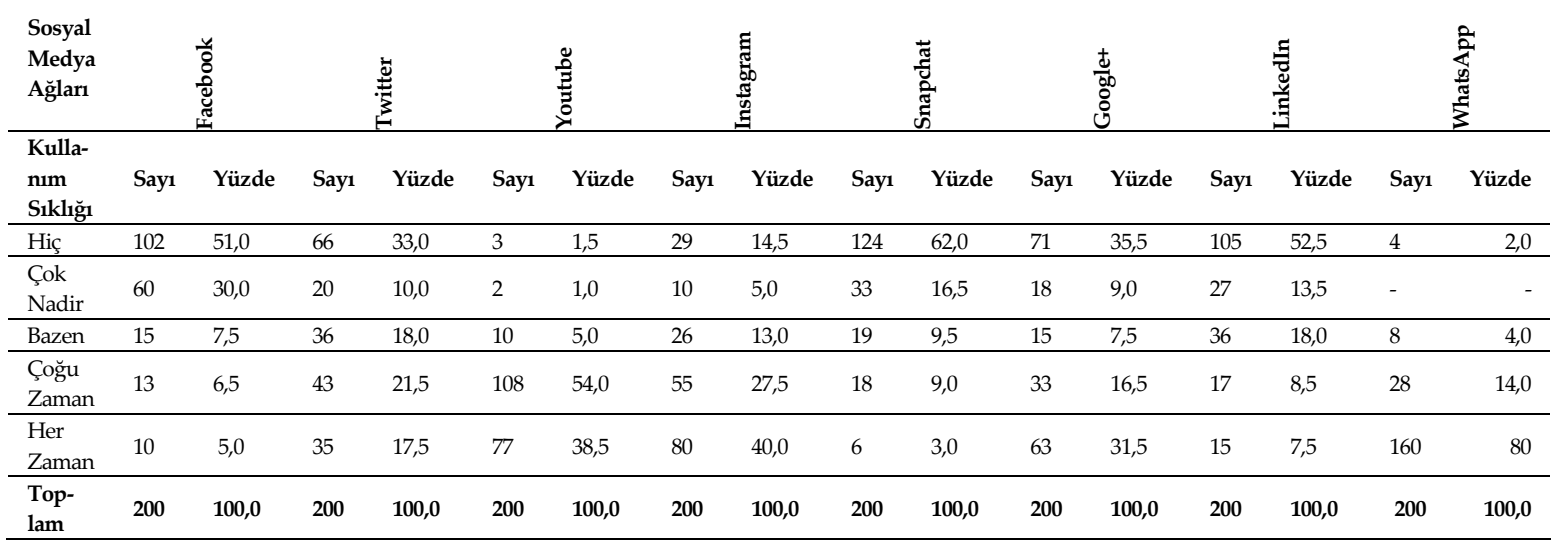

Sosyal medya uygulamalarının kullanım sıklığının ölçüldüğü sorudan elde edilen ve Tablo 4 'te gösterilen verilere göre katılımclların sosyal medya uygulamaları arasında çoğunlukla WhatsApp, YouTube ve Instagram uygulamalarını kullandıkları belirlenmiştir. Aynı zamanda katılımcıların, Linkedin, Snapchat ve Facebook gibi uygulamaları neredeyse hiç kullanmadıkları tespit edilmiştir.

Tablo 5. Sosyal Medya Uygulamalarnnda Günlük Geçirilen Süreler

\begin{tabular}{|c|c|c|c|c|c|c|c|c|c|c|c|c|c|c|c|c|}
\hline \multirow{2}{*}{$\begin{array}{l}\text { Sosyal } \\
\text { Medya } \\
\text { Ağlar }\end{array}$} & \multicolumn{2}{|c|}{ 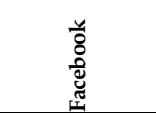 } & \multicolumn{2}{|c|}{ 壱 } & \multicolumn{2}{|c|}{ 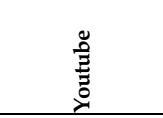 } & \multicolumn{2}{|c|}{ 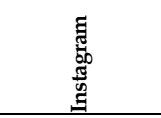 } & \multicolumn{2}{|c|}{ 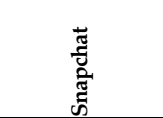 } & \multicolumn{2}{|c|}{$\begin{array}{l} \pm \\
\frac{ \pm}{00} \\
8 \\
0\end{array}$} & \multicolumn{2}{|c|}{ 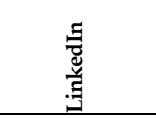 } & \multicolumn{2}{|c|}{ 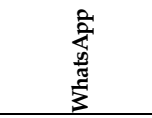 } \\
\hline & Sayı & Yüzde & Sayı & Yüzde & Say1 & Yüzde & Sayı & Yüzde & Sayı & Yüzde & Sayı & Yüzde & Sayı & Yüzde & Sayı & Yüzde \\
\hline 0. & 22 & 11,0 & 27 & 13,5 & - & - & 12 & 6,0 & 41 & 20,5 & 23 & 11,5 & 25 & 12,5 & 6 & 3,0 \\
\hline $\begin{array}{l}1 \text { Saat- } \\
\text { ten } \mathrm{Az}\end{array}$ & 142 & 71,0 & 90 & 45,0 & 35 & 17,5 & 57 & 28,5 & 129 & 64,5 & 97 & 48,5 & 132 & 66,0 & 16 & 8,0 \\
\hline $\begin{array}{l}1-2 \\
\text { Saat }\end{array}$ & 14 & 7,0 & 47 & 23,5 & 64 & 32,0 & 42 & 21,0 & 7 & 3,5 & 20 & 10,0 & 11 & 5,5 & 54 & 27,0 \\
\hline $\begin{array}{l}2-3 \\
\text { Saat }\end{array}$ & 3 & 1,5 & 11 & 5,5 & 42 & 21,0 & 38 & 19,0 & 2 & 1,0 & 17 & 8,5 & 7 & 3,5 & 34 & 17,0 \\
\hline $\begin{array}{l}3-4 \\
\text { Saat }\end{array}$ & - & - & 7 & 3,5 & 21 & 10,5 & 19 & 9,5 & 4 & 2,0 & 10 & 5,0 & 4 & 2,0 & 21 & 10,5 \\
\hline $\begin{array}{l}4-5 \\
\text { Saat }\end{array}$ & - & - & 7 & 3,5 & 16 & 8,0 & 16 & 8,0 & 4 & 2,0 & 10 & 5,0 & 5 & 2,5 & 26 & 13,0 \\
\hline $\begin{array}{l}5 \text { Saat- } \\
\text { ten } \\
\text { Fazla }\end{array}$ & 1 &, 5 & 5 & 2,5 & 16 & 8,0 & 10 & 5,0 & 1 &, 5 & 5 & 2,5 & 1 &, 5 & 30 & 15,0 \\
\hline $\begin{array}{l}\text { Kayıp } \\
\text { Değer }\end{array}$ & 18 & 9,0 & 6 & 3,0 & 6 & 3,0 & 6 & 3,0 & 12 & 6,0 & 18 & 9,0 & 15 & 7,5 & 13 & 6,5 \\
\hline $\begin{array}{l}\text { Top- } \\
\text { lam }\end{array}$ & 200 & 100,0 & 200 & 100,0 & 200 & 100,0 & 200 & 100,0 & 200 & 100,0 & 200 & 100,0 & 200 & 100,0 & 200 & 100,0 \\
\hline
\end{tabular}


Bireylerin gündelik hayatında sosyal medya oldukça önemli bir role sahiptir. Sosyal medya araçlarında günlük geçirilen sürelerin ölçüldügü Tablo 5'e göre katılımcıların çoğunluğu günlük 1-3 saat aralığında sosyal medya araçlarını kullanmaktadır. Gündelik yaşamda en uzun süre kullanılan sosyal medya uygulamasının ise çoğunlukla WhatsApp ve YouTube olduğu belirlenmiştir.

\section{Haber Elde Etme Sürecinde İletişim Araçlarının Kullanımı}

Bu bölümde; haber elde etme sürecinde kullanılan iletişim araçlarına ilişkin ve bu araçların tercih edilme sebepleri ile ilgili bulgular yer almaktadır.

Tablo 6. Haber Elde Etme/Bilgilenme Sürecinde Kullanılan İletişim Araçlarn

\begin{tabular}{lllllllllll}
\hline $\begin{array}{l}\text { İletişim } \\
\text { Araçları }\end{array}$ & \multicolumn{2}{l}{ Televizyon } & Gazete & & Radyo & & Web Siteleri & $\begin{array}{l}\text { Sosyal Medya } \\
\text { Uygulamaları }\end{array}$ \\
\hline $\begin{array}{l}\text { Kullanım } \\
\text { Sıklığı }\end{array}$ & Sayı & Yüzde & Sayı & Yüzde & Sayı & Yüzde & Sayı & Yüzde & Sayı & Yüzde \\
\hline Hiç & 45 & 22,5 & 77 & 38,5 & 89 & 44,5 & 2 & 1,0 & 11 & 5,5 \\
\hline Çok Nadir & 60 & 30,0 & 62 & 31,0 & 52 & 26,0 & 1 &, 5 & 7 & 3,5 \\
\hline Bazen & 39 & 19,5 & 29 & 14,5 & 27 & 13,5 & 17 & 8,5 & 39 & 19,5 \\
\hline $\begin{array}{l}\text { Çoğu } \\
\text { Zaman }\end{array}$ & 36 & 18,0 & 15 & 7,5 & 10 & 5,0 & 80 & 40,0 & 55 & 27,5 \\
\hline Her Zaman & 16 & 8,0 & 6 & 3,0 & 6 & 3,0 & 97 & 48,5 & 80 & 40,0 \\
\hline $\begin{array}{l}\text { Kayıp } \\
\text { Değer }\end{array}$ & 4 & 2,0 & 11 & 5,5 & 16 & 8,0 & 3 & 1,5 & 8 & 4,0 \\
\hline Toplam & $\mathbf{2 0 0}$ & $\mathbf{1 0 0 , 0}$ & $\mathbf{2 0 0}$ & $\mathbf{1 0 0 , 0}$ & $\mathbf{2 0 0}$ & $\mathbf{1 0 0 , 0}$ & $\mathbf{2 0 0}$ & $\mathbf{1 0 0 , 0}$ & $\mathbf{2 0 0}$ & $\mathbf{1 0 0 , 0}$ \\
\hline
\end{tabular}

Bireyler haber elde etme/bilgilenme sürecinde farklı iletişim araçlarını kullanabilmektedir. Geleneksel medya araçları haber elde etme sürecinde sıkça kullanılırken, günümüzde yeni iletişim teknolojilerinin gelişimi ile birlikte haber elde etme sürecinde sosyal medya araçları daha fazla tercih edilir hale gelmiştir. Haber elde etme sürecinde kullanılan iletişim araçlarının tespit edildiği Tablo 6'ya göre katılımcıların büyük bir çoğunluğu web siteleri ve sosyal medya uygulamaları ile habere erişim sağlamaktadır. Bununla birlikte televizyon, gazete ve radyo gibi iletişim araçlarının haber elde etme sürecinde çoğunlukla kullanılmadığı belirlenmiştir. 
Tablo 7. Haberlere Online Ortamda Erişme Yöntemleri

\begin{tabular}{|c|c|c|c|c|c|c|c|c|c|c|c|c|c|c|}
\hline \multirow{2}{*}{$\begin{array}{l}\text { Erişim } \\
\text { Sağlama Yöntemi } \\
\text { Kullanım Sıklığı } \\
\end{array}$} & \multicolumn{2}{|c|}{$\begin{array}{l}\text { Arama motor- } \\
\text { larının yön- } \\
\text { lendirme-sini } \\
\text { kullanarak }\end{array}$} & \multicolumn{2}{|c|}{$\begin{array}{l}\text { Resmi } \\
\text { haber/bilgi } \\
\text { kaynaklarını } \\
\text { kullanarak }\end{array}$} & \multicolumn{2}{|c|}{$\begin{array}{l}\text { Gazetelerin } \\
\text { web sitelerini } \\
\text { (URL) adres } \\
\text { çubuğuna } \\
\text { yazarak }\end{array}$} & \multicolumn{2}{|c|}{$\begin{array}{l}\text { Forum } \\
\text { sayfalarının } \\
\text { yönlendirme- } \\
\text { sinden } \\
\text { faydalanarak }\end{array}$} & \multicolumn{2}{|c|}{$\begin{array}{l}\text { Gazetelerin } \\
\text { sosyal medya } \\
\text { hesaplarını } \\
\text { kullanarak/ta- } \\
\text { kip ederek }\end{array}$} & \multicolumn{2}{|c|}{$\begin{array}{l}\text { Sosyal medya } \\
\text { araçlarının } \\
\text { yönlendirme- } \\
\text { lerini } \\
\text { kullanarak }\end{array}$} & \multicolumn{2}{|c|}{$\begin{array}{l}\text { Online haber } \\
\text { sayfalarının } \\
\text { mobile uygu- } \\
\text { lamalarını } \\
\text { kullanarak }\end{array}$} \\
\hline & Sayı & Yüzde & Sayı & Yüzde & Say1 & Yüzde & Say1 & Yüzde & Sayı & Yüzde & Say1 & Yüzde & Sayı & Yüzde \\
\hline Hiç & 5 & 2,5 & 7 & 3,5 & 35 & 17,5 & 62 & 31,0 & 69 & 34,5 & 37 & 18,5 & 82 & 41,0 \\
\hline Çok Nadir & 20 & 10,0 & 18 & 9,0 & 51 & 25,5 & 61 & 30,5 & 23 & 11,5 & 37 & 18,5 & 27 & 13,5 \\
\hline Bazen & 49 & 24,5 & 61 & 30,5 & 31 & 15,5 & 38 & 19,0 & 28 & 14,0 & 43 & 21,5 & 28 & 14,0 \\
\hline Çoğu Zaman & 66 & 33,0 & 69 & 34,5 & 40 & 20,0 & 17 & 8,5 & 42 & 21,0 & 42 & 21,0 & 25 & 12,5 \\
\hline Her Zaman & 56 & 28,0 & 42 & 21,0 & 33 & 16,5 & 5 & 2,5 & 28 & 14,0 & 30 & 15,0 & 27 & 13,5 \\
\hline Kayıp Değer & 4 & 2,0 & 3 & 1,5 & 10 & 5,0 & 17 & 8,5 & 10 & 5,0 & 11 & 5,5 & 11 & 5,5 \\
\hline Toplam & 200 & 100,0 & 200 & 100,0 & 200 & 100,0 & 200 & 100,0 & 200 & 100,0 & 200 & 100,0 & 200 & 100,0 \\
\hline
\end{tabular}

Tablo 6'da bireylerin haber elde etme sürecinde çoğunlukla web sitelerini ve sosyal medya araçlarını kullandıkları görülmektedir. Tablo 7'de ise bireylerin haberlere online ortamda erişim yöntemlerine ilişkin veriler yer almaktadır. Elde edilen bulgulara göre, katılımcıların habere erişim sürecinde çoğunlukla arama motorlarının yönlendirmesinden faydalandığı, resmi haber/bilgi kaynaklarını kullandı̆̆ı ve sosyal medya araçlarının yönlendirmesi aracılığı ile habere erişim sağladığı belirlenmiştir. Ayrıca katılımcıların online haber sayfalarının mobil uygulamalarını oldukça az tercih ettiği gözlemlenmiştir. Dolayısıyla, habere erişim sürecinde arama motorlarının ne kadar etkin rol oynadığını bu tablodan hareketle söylemek mümkün gözükmektedir.

Tablo 8.1 Haberlere Ulaşma ve Bilgi Edinme Sürecinde Kullanılan Araçlarn Tercih Edilmesindeki Temel Etmenler

\begin{tabular}{|c|c|c|c|c|c|c|c|c|c|c|}
\hline \multirow{2}{*}{$\begin{array}{l}\text { Tercih } \\
\text { Sebepleri } \\
\text { Kullanım } \\
\text { S1klığı } \\
\end{array}$} & \multicolumn{2}{|c|}{$\begin{array}{c}\text { Haberlere/ } \\
\text { bilgilere erişim } \\
\text { sağlama } \\
\text { olanaklarına } \\
\text { dikkat ederim. }\end{array}$} & \multicolumn{2}{|c|}{$\begin{array}{c}\text { Haberlerin/ } \\
\text { bilgilerin güncel } \\
\text { olmasına dikkat } \\
\text { ederim. }\end{array}$} & \multicolumn{2}{|c|}{$\begin{array}{l}\text { Ücretsiz } \\
\text { olmas1. }\end{array}$} & \multicolumn{2}{|c|}{$\begin{array}{c}\text { Etkileşime } \\
\text { imkân } \\
\text { sağlamasına } \\
\text { önem gösteririm. }\end{array}$} & \multicolumn{2}{|c|}{$\begin{array}{l}\text { Arşiv bilgilerine } \\
\text { erişebilme olanağ } \\
\text { benim için } \\
\text { önemlidir. }\end{array}$} \\
\hline & Sayı & Yüzde & Sayı & Yüzde & Sayı & Yüzde & Sayı & Yüzde & Sayı & Yüzde \\
\hline $\begin{array}{l}\text { Kesinlikle } \\
\text { Katılmıyorum }\end{array}$ & 9 & 4,5 & 3 & 1,5 & 1 & 0,5 & 17 & 8,5 & 7 & 3,5 \\
\hline Katılmıyorum & 5 & 2,5 & 7 & 3,5 & 11 & 5,5 & 36 & 18,0 & 20 & 10,0 \\
\hline Kararsızım & 22 & 11,0 & 11 & 5,5 & 21 & 10,5 & 51 & 25,5 & 36 & 18,0 \\
\hline Katıliyorum & 98 & 49,0 & 79 & 39,5 & 90 & 45,0 & 52 & 26,0 & 77 & 38,5 \\
\hline $\begin{array}{l}\text { Kesinlikle } \\
\text { Katıliyorum } \\
\end{array}$ & 54 & 27,0 & 89 & 44,5 & 68 & 34,0 & 29 & 14,5 & 40 & 20,0 \\
\hline Kayıp Değer & 12 & 6,0 & 11 & 5,5 & 9 & 4,5 & 15 & 7,5 & 20 & 10,0 \\
\hline Toplam & 200 & 100,0 & 200 & 100,0 & 200 & 100,0 & 200 & 100,0 & 200 & 100,0 \\
\hline
\end{tabular}


Tablo 8.2 Haberlere Ulaşma ve Bilgi Edinme Sürecinde Kullanılan Araçlarn Tercih Edilmesindeki Temel Etmenler

\begin{tabular}{|c|c|c|c|c|c|c|c|c|}
\hline \multirow{2}{*}{$\begin{array}{l}\text { Tercih } \\
\text { Sebepleri } \\
\text { Kullanım } \\
\text { Sıklığı } \\
\end{array}$} & \multicolumn{2}{|c|}{$\begin{array}{l}\text { Konu ile ilgili } \\
\text { ayrıntılı bilgi ve } \\
\text { haberlere ulaşmak } \\
\text { isterim. }\end{array}$} & \multicolumn{2}{|c|}{$\begin{array}{c}\text { Karşılaştırma } \\
\text { yapabilmek, farklı } \\
\text { kaynaklara } \\
\text { erişebilmek } \\
\text { isterim. }\end{array}$} & \multicolumn{2}{|c|}{$\begin{array}{c}\text { Görsel, işitsel ve } \\
\text { yazılı verilerin aynı } \\
\text { ortamda } \\
\text { bulunmasına önem } \\
\text { gösteririm. }\end{array}$} & \multicolumn{2}{|c|}{$\begin{array}{l}\text { Sansür edilmemiş } \\
\text { haberlerin/ } \\
\text { bilgilerin olduğu } \\
\text { araçları tercih } \\
\text { ederim. }\end{array}$} \\
\hline & Sayı & Yüzde & Sayı & Yüzde & Sayı & Yüzde & Sayı & Yüzde \\
\hline Kesinlikle & & & & & & & & \\
\hline Katılmiyorum & 4 & 2,0 & 6 & 3,0 & 1 & 0,5 & 7 & 3,5 \\
\hline Katılmıyorum & 4 & 2,0 & 2 & 1,0 & 1 & 0,5 & 8 & 4,0 \\
\hline Kararsızım & 15 & 7,5 & 16 & 8,0 & 29 & 14,5 & 22 & 11,0 \\
\hline Katıliyorum & 78 & 39,0 & 69 & 34,5 & 94 & 47,0 & 56 & 28,0 \\
\hline $\begin{array}{l}\text { Kesinlikle } \\
\text { Katıliyorum }\end{array}$ & 88 & 44,0 & 93 & 46,5 & 61 & 30,5 & 90 & 45,0 \\
\hline Kayıp Değer & 11 & 5,5 & 14 & 7,0 & 14 & 7,0 & 17 & 8,5 \\
\hline Toplam & 200 & 100,0 & 200 & 100,0 & 200 & 100,0 & 200 & 100,0 \\
\hline
\end{tabular}

Bireyler, habere erişim sürecinde farklı iletişim araçlarını pek çok sebeple tercih edebilmektedir. Bu bağlamda, Tablo 8' de aktarılan verilere göre habere ulaşma ve bilgi edinme sürecinde kullanılan araçların tercih edilmesinde şu faktörler etkili olmaktadır:

- Haberlerin/bilgilerin güncel olması ( $\mathrm{f}=168, \%$ 84).

- Konu ile ilgili ayrıntılı bilgi ve haberlere ulaşılabilmesi ( $\mathrm{f}=166, \% 83$ ).

- Karşılaştırma yapabilme ve farklı kaynaklara erişim imkânının olması (f $=162, \% 81$ ).

- Ücretsiz olması ( $\mathrm{f}=158, \% 79$ ).

- Görsel, işitsel ve yazılı verilerin aynı ortamda bulunması ( $\mathrm{f}=155, \% 77,5)$.

- Haberlere/bilgilere erişim sağlama olanaklarına ( $\mathrm{f}=152, \% 76)$.

- Arşiv bilgilerine erişim sağlanabilmesi ( $\mathrm{f}=117, \% 58,5)$.

- Sansür edilmemiş haberlerin/bilgilerin olması ( $\mathrm{f}=146, \% 73)$

- Etkileşime imkân sağlaması ( $\mathrm{f}=81, \% 40,5)$.

Bu bağlamda katılımcılar, habere erişim sürecinde çoğunlukla haberlerin/bilgilerin güncel olması; konu ile ilgili ayrıntılı bilgi ve habere ulaşabilmesi ve karşılaştırma yapabilmesi, farklı kaynaklara erişim imkânına sahip olabilme sebeplerine göre iletişim araçlarını tercih etmektedir. 


\section{Haber Elde Etme Sürecinde Sosyal Medya Araçlarmmn Rolü}

Haber elde etme sürecinde sosyal medya araçlarının rolüne ve bu araçların tercih edilme sebeplerine ilişkin bulgular şu şekildedir:

Tablo 9. Sosyal Medya Uygulamalarn ile Haber Elde Etme/Bilgilenme Sürecinde Kullantlan Teknolojik Araçlar

\begin{tabular}{lllllll}
\hline Teknolojik Araçlar: & \multicolumn{2}{l}{ Bilgisayar (Masaüstü/Dizüstü) } & \multicolumn{2}{l}{ Cep Telefonu } & Tablet \\
\hline Kullanım Sıklığı & Sayı & Yüzde & Sayı & Yüzde & Sayı & Yüzde \\
\hline Hiç & 11 & 5,5 & 0 & 0 & 86 & 43,0 \\
\hline Çok Nadir & 23 & 11,5 & 3 & 1,5 & 40 & 20,0 \\
\hline Bazen & 58 & 29,0 & 5 & 2,5 & 16 & 8,0 \\
\hline Çoğu Zaman & 59 & 29,5 & 65 & 32,5 & 12 & 6,0 \\
\hline Her Zaman & 39 & 19,5 & 119 & 59,5 & 29 & 14,5 \\
\hline Kayıp Değer & 10 & 5,0 & 8 & 4,0 & 17 & 8,5 \\
\hline Toplam & $\mathbf{2 0 0}$ & $\mathbf{1 0 0 , 0}$ & $\mathbf{2 0 0}$ & $\mathbf{1 0 0 , 0}$ & $\mathbf{2 0 0}$ & $\mathbf{1 0 0 , 0}$ \\
\hline
\end{tabular}

Habere erişim sürecinde sosyal medya uygulamalarının aktif olarak kullanıldığı belirlenmiştir. Tablo 9' dan elde edilen verilere göre ise katılımcların sosyal medya uygulamaları ile habere erişim sürecinde çoğunlukla cep telefonunu tercih ettikleri, cep telefonları aracilığı ile sosyal medya uygulamaları vasıtasıyla haberlere erişim sağladıkları ve bu süreçte kısmen de olsa bilgisayarı kullandıkları tespit edilmiştir.

Tablo 10. Habere Ulaşım Sürecinde Kullanılan Sosyal Medya Ağlan

\begin{tabular}{|c|c|c|c|c|c|c|c|c|c|c|c|c|c|c|c|c|}
\hline $\begin{array}{l}\text { Sosyal } \\
\text { Medya } \\
\text { Ağlar }\end{array}$ & & 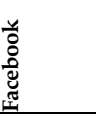 & & 売 & & 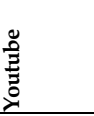 & & 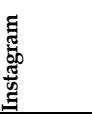 & & 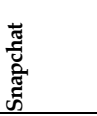 & & $\begin{array}{l}\frac{t}{00} \\
8 \\
0\end{array}$ & & 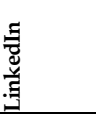 & & 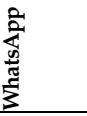 \\
\hline $\begin{array}{l}\text { Kulla- } \\
\text { num } \\
\text { Sıklığı }\end{array}$ & Sayı & Yüzde & Sayı & Yüzde & Sayı & Yüzde & Sayı & Yüzde & Sayı & Yüzde & Sayı & Yüzde & Sayı & Yüzde & Sayı & Yüzde \\
\hline Hiç & 118 & 59,0 & 69 & 34,5 & 17 & 8,5 & 35 & 17,5 & 138 & 69,0 & 89 & 44,5 & 116 & 58,0 & 37 & 18,5 \\
\hline $\begin{array}{l}\text { Çok } \\
\text { Nadir }\end{array}$ & 33 & 16,5 & 14 & 7,0 & 42 & 21,0 & 23 & 11,5 & 17 & 8,5 & 16 & 8,0 & 32 & 16,0 & 15 & 7,5 \\
\hline Bazen & 19 & 9,5 & 28 & 14,0 & 65 & 32,5 & 43 & 21,5 & 5 & 2,5 & 29 & 14,5 & 17 & 8,5 & 52 & 26,0 \\
\hline $\begin{array}{l}\text { Çoğu } \\
\text { Zaman }\end{array}$ & 8 & 4,0 & 38 & 19,0 & 28 & 14,0 & 41 & 20,5 & 10 & 5,0 & 21 & 10,5 & 8 & 4,0 & 30 & 15,0 \\
\hline $\begin{array}{l}\text { Her } \\
\text { Zaman } \\
\end{array}$ & 9 & 4,5 & 34 & 17,0 & 36 & 18,0 & 43 & 21,5 & 1 &, 5 & 30 & 15,0 & 5 & 2,5 & 44 & 22,0 \\
\hline $\begin{array}{l}\text { Kayıp } \\
\text { Değer }\end{array}$ & 13 & 6,5 & 17 & 8,5 & 12 & 6,0 & 15 & 7,5 & 29 & 14,5 & 15 & 7,5 & 22 & 11,0 & 22 & 11,0 \\
\hline $\begin{array}{l}\text { Top- } \\
\text { lam }\end{array}$ & 200 & 100,0 & 200 & 100,0 & 200 & 100,0 & 200 & 100,0 & 200 & 100,0 & 200 & 100,0 & 200 & 100,0 & 200 & 100,0 \\
\hline
\end{tabular}


Tablo 10'a göre katılımclar, habere ulaşma sürecinde Instagram, WhatsApp, Twitter ve YouTube uygulamalarını sıklıkla tercih etmektedir. Ayrıca, bireylerin habere ulaşma sürecinde genellikle mobil telefon araçları ile kullanılan Instagram ve WhatsApp gibi uygulamaların fazla kullanması dikkat çekicidir.

Tablo 11.1 Habere Ulaşma Sürecinde Sosyal Medya Araçlarnnın Tercih Edilme Sebepleri

\begin{tabular}{|c|c|c|c|c|c|c|c|c|c|c|}
\hline \multirow{2}{*}{$\begin{array}{l}\text { Tercih Sebepleri } \\
\text { Kullanım Sıklığı }\end{array}$} & \multicolumn{2}{|c|}{$\begin{array}{c}\text { Haberlere } \\
\text { erişimin } \\
\text { ücretsiz olması } \\
\text { veya daha ucuz } \\
\text { olması. }\end{array}$} & \multicolumn{2}{|c|}{$\begin{array}{l}\text { Habere anında } \\
\text { erişebilme } \\
\text { imkânının } \\
\text { bulunması. }\end{array}$} & \multicolumn{2}{|c|}{$\begin{array}{c}\text { Geleneksel ileti- } \\
\text { şim araçlarında } \\
\text { yer almayan ha- } \\
\text { ber ve bilgilere } \\
\text { ulaşabilme. }\end{array}$} & \multicolumn{2}{|c|}{$\begin{array}{c}\text { Alternatif } \\
\text { haber/bilgi kay- } \\
\text { naklarına erişim } \\
\text { sağlayabilme. }\end{array}$} & \multicolumn{2}{|c|}{$\begin{array}{c}\text { Sürekli } \\
\text { güncellenebilir } \\
\text { özelliğinin olması. }\end{array}$} \\
\hline & Sayı & Yüzde & Sayı & Yüzde & Sayı & Yüzde & Sayı & Yüzde & Sayı & Yüzde \\
\hline Hiç & 16 & 8,0 & 10 & 5,0 & 10 & 5,0 & 5 & 2,5 & 1 &, 5 \\
\hline Çok Nadir & 18 & 9,0 & 5 & 2,5 & 18 & 9,0 & 5 & 2,5 & 8 & 4,0 \\
\hline Bazen & 33 & 16,5 & 18 & 9,0 & 31 & 15,5 & 26 & 13,0 & 22 & 11,0 \\
\hline Çoğu Zaman & 74 & 37,0 & 67 & 33,5 & 59 & 29,5 & 70 & 35,0 & 58 & 29,0 \\
\hline Her Zaman & 51 & 25,5 & 89 & 44,5 & 72 & 36,0 & 78 & 39,0 & 103 & 51,5 \\
\hline Kayıp Değer & 8 & 4,0 & 11 & 5,5 & 10 & 5,0 & 16 & 8,0 & 8 & 4,0 \\
\hline Toplam & 200 & 100,0 & 200 & 100,0 & 200 & 100,0 & 200 & 100,0 & 200 & 100,0 \\
\hline
\end{tabular}

Tablo 11.2 Habere Ulaşma Sürecinde Sosyal Medya Araçlarnnı Tercih Edilme Sebepleri

\begin{tabular}{|c|c|c|c|c|c|c|c|c|c|c|c|c|}
\hline \multirow{2}{*}{$\begin{array}{l}\text { Tercih Sebepleri } \\
\text { Kullanım Sıklığı }\end{array}$} & \multicolumn{2}{|c|}{$\begin{array}{l}\text { Sadece yazı } \\
\text { değil, fotoğraf } \\
\text { ve video gibi } \\
\text { içeriklerin de } \\
\text { yer alması. }\end{array}$} & \multicolumn{2}{|c|}{$\begin{array}{c}\text { Arşiv } \\
\text { tutabilmeye, } \\
\text { imkân tanıması. }\end{array}$} & \multicolumn{2}{|c|}{$\begin{array}{l}\text { Kişisel ilgi ve } \\
\text { istek doğrultu- } \\
\text { sundaki } \\
\text { haberlere ulaşa- } \\
\text { bilme imkânının } \\
\text { olması. } \\
\end{array}$} & \multicolumn{2}{|c|}{$\begin{array}{l}\text { Haberler ile ilgili } \\
\text { yorum ve düşün- } \\
\text { celerimi iletebil- } \\
\text { meme imkân } \\
\text { tanıması. }\end{array}$} & \multicolumn{2}{|c|}{$\begin{array}{l}\text { Daha anlaşılır } \\
\text { bir haber dilinin } \\
\text { kullanılması. }\end{array}$} & \multicolumn{2}{|c|}{$\begin{array}{l}\text { Karşılıklı etkile- } \\
\text { şime olanak } \\
\text { tanıması. }\end{array}$} \\
\hline & Sayı & Yüzde & Sayı & Yüzde & Sayı & Yüzde & Sayı & Yüzde & Sayı & Yüzde & Sayı & Yüzde \\
\hline Hiç & 7 & 3,5 & 13 & 6,5 & 8 & 4,0 & 27 & 13,5 & 23 & 11,5 & 30 & 15,0 \\
\hline Çok Nadir & 7 & 3,5 & 18 & 9,0 & 11 & 5,5 & 29 & 14,5 & 18 & 9,0 & 27 & 13,5 \\
\hline Bazen & 18 & 9,0 & 30 & 15,0 & 26 & 13,0 & 66 & 33,0 & 49 & 24,5 & 47 & 23,5 \\
\hline Çoğu Zaman & 60 & 30,0 & 70 & 35,0 & 87 & 43,5 & 41 & 20,5 & 63 & 31,5 & 56 & 28,0 \\
\hline Her Zaman & 98 & 49,0 & 49 & 24,5 & 49 & 24,5 & 24 & 12,0 & 36 & 18,0 & 23 & 11,5 \\
\hline Kayıp Değer & 10 & 5,0 & 20 & 10,0 & 22 & 11,0 & 16 & 8,0 & 14 & 7,0 & 17 & 8,5 \\
\hline Toplam & 200 & 100,0 & 200 & 100,0 & 200 & 100,0 & 200 & 100,0 & 200 & 100,0 & 200 & 100,0 \\
\hline
\end{tabular}


Habere erişim sürecinde sıkça tercih edilen iletişim araçlarından olan sosyal medya uygulamaları farklı sebeplerle bireyler tarafından kullanılabilmektedir. Tablo 11'e göre katılımcların habere erişim sürecinde sosyal medya araçlarını tercih etmelerindeki en önemli faktörler şunlardır:

- Sürekli güncellenebilir özelliğinin olması ( $f=161, \% 80,5)$.

- Sadece yazı değil, fotoğraf ve video gibi içeriklerin de yer alması ( $\mathrm{f}=158$, $\% 79)$.

- Habere anında erişim imkânının bulunması ( $\mathrm{f}=156, \% 78)$.

- Alternatif haber/bilgi kaynaklarına erişim ( $\mathrm{f}=148, \% 74$ ).

- Kişisel ilgi ve istek doğrultusundaki haberlere ulaşılabilme imkânının olmasi ( $\mathrm{f}=136, \% 68)$.

Görülebileceği üzere bireylerin sosyal medya araçlarını tercih etmelerinde yeni medyanın sağlamış olduğu teknik imkânların önemli bir rolü bulunmaktadır.

Tablo 12. Haber Elde Etme Sürecinde Gazetelere Erişim Sağlama Şekli

\begin{tabular}{|c|c|c|c|c|c|c|c|c|}
\hline \multirow{2}{*}{$\begin{array}{l}\text { Gazetelere Erişim Yöntemi } \\
\text { Kullanım Sıklığı }\end{array}$} & \multicolumn{2}{|c|}{$\begin{array}{l}\text { Bayiden gazete } \\
\text { satın alarak. }\end{array}$} & \multicolumn{2}{|c|}{$\begin{array}{l}\text { Gazetelerin web } \\
\text { ortamindaki haber } \\
\text { sitesini kullanarak. }\end{array}$} & \multicolumn{2}{|c|}{$\begin{array}{l}\text { Online } \\
\text { abonelik ile } \\
\text { e-gazete } \\
\text { takibi } \\
\text { yaparak. }\end{array}$} & \multicolumn{2}{|c|}{$\begin{array}{l}\text { Gazetelerin sos- } \\
\text { yal medya uygu- } \\
\text { lamalarinı } \\
\text { kullanarak/ } \\
\text { takip ederek. }\end{array}$} \\
\hline & Sayı & Yüzde & Sayı & Yüzde & Sayı & Yüzde & Sayı & Yüzde \\
\hline Hiç & 92 & 46,0 & 14 & 7,0 & 113 & 56,5 & 52 & 26,0 \\
\hline Çok Nadir & 54 & 27,0 & 21 & 10,5 & 33 & 16,5 & 15 & 7,5 \\
\hline Bazen & 31 & 15,5 & 47 & 23,5 & 21 & 10,5 & 37 & 18,5 \\
\hline Çoğu Zaman & 8 & 4,0 & 69 & 34,5 & 11 & 5,5 & 52 & 26,0 \\
\hline Her Zaman & 2 & 1,0 & 43 & 21,5 & 6 & 3,0 & 34 & 17,0 \\
\hline Kayıp Değer & 13 & 6,5 & 6 & 3,0 & 16 & 8,0 & 10 & 5,0 \\
\hline Toplam & 200 & 100,0 & 200 & 100,0 & 200 & 100,0 & 200 & 100,0 \\
\hline
\end{tabular}

Toplumu bilgilendirme, haber verme misyonu bulunan gazeteler, iletişim teknolojilerinin gelişimi ile birlikte biçim değiştirmiş, online ortamlarda yer edinmeye başlamışlardır. Bu durum, dolaylı olarak bireylerin gazeteye erişim şeklini de değiştirmiştir. Tablo 12'ye göre katılımclların büyük bir çoğunluğu gazetelerin web ortamındaki haber sitelerini kullanarak veya gazetelerin sosyal medya uygulamalarını kullanarak/takip ederek gazetelere erişim sağlamaktadır. Katılımcıların büyük bir çoğunluğu ise bayiden gazete satın almadığını, online abonelik ile de e-gazete takibi yapmadığını belirtmiştir. 
Tablo 13. Takip Edilen Gazetelerin Kullanılan Sosyal Medya Hesaplan

\begin{tabular}{|c|c|c|c|c|c|c|c|c|c|c|c|c|c|c|c|c|}
\hline $\begin{array}{l}\text { Sosyal } \\
\text { Medya } \\
\text { Ağları }\end{array}$ & & 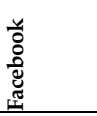 & & 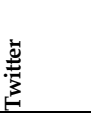 & & 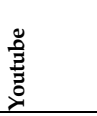 & & 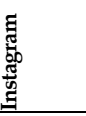 & & 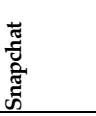 & & $\begin{array}{l}\frac{t}{00} \\
0 \\
0 \\
0\end{array}$ & & 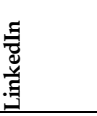 & & $\begin{array}{l}\sum_{1}^{2} \\
\text { 章 } \\
\text { है } \\
\sum_{3}^{2}\end{array}$ \\
\hline $\begin{array}{l}\text { Kulla- } \\
\text { nım } \\
\text { Sıklığı }\end{array}$ & Sayı & Yüzde & Sayı & Yüzde & Sayı & Yüzde & Sayı & Yüzde & Sayı & Yüzde & Sayı & Yüzde & Say1 & Yüzde & Sayı & Yüzde \\
\hline Hiç & 136 & 68,0 & 90 & 45,0 & 72 & 36,0 & 97 & 48,5 & 149 & 74,5 & 117 & 58,5 & 142 & 71,0 & 115 & 57,5 \\
\hline $\begin{array}{l}\text { Çok } \\
\text { Nadir } \\
\end{array}$ & 28 & 14,0 & 7 & 3,5 & 29 & 14,5 & 16 & 8,0 & 9 & 4,5 & 14 & 7,0 & 21 & 10,5 & 23 & 11,5 \\
\hline Bazen & 10 & 5,0 & 20 & 10,0 & 40 & 20,0 & 14 & 7,0 & 5 & 2,5 & 16 & 8,0 & 9 & 4,5 & 19 & 9,5 \\
\hline $\begin{array}{l}\text { Çoğu } \\
\text { Zaman }\end{array}$ & 4 & 2,0 & 37 & 18,5 & 19 & 9,5 & 36 & 18,0 & 8 & 4,0 & 17 & 8,5 & 6 & 3,0 & 6 & 3,0 \\
\hline $\begin{array}{l}\text { Her } \\
\text { Zaman }\end{array}$ & 5 & 2,5 & 33 & 16,5 & 23 & 11,5 & 27 & 13,5 & 5 & 2,5 & 24 & 12,0 & 4 & 2,0 & 20 & 10,0 \\
\hline $\begin{array}{l}\text { Kayıp } \\
\text { Değer }\end{array}$ & 17 & 8,5 & 13 & 6,5 & 17 & 8,5 & 10 & 5,0 & 24 & 12,0 & 12 & 6,0 & 18 & 9,0 & 17 & 8,5 \\
\hline $\begin{array}{l}\text { Top- } \\
\text { lam }\end{array}$ & 200 & 100,0 & 200 & 100,0 & 200 & 100,0 & 200 & 100,0 & 200 & 100,0 & 200 & 100,0 & 200 & 100,0 & 200 & 100,0 \\
\hline
\end{tabular}

Günümüzde gazetelerin sanal ortamlar aracılığı ile takip edildiğini ifade etmek mümkündür. Bu noktada özellikle sosyal medya uygulamaları etkin bir rol üstlenmekte, gazeteler tarafından aktif bir şekilde kullanılmaktadır. Tablo 13'e göre de habere erişim sürecinde gazetelerin sosyal medya hesaplarını tercih eden katılımcılar; diğer sosyal medya uygulamalarına oranla, çoğunlukla gazetelerin Twitter, Instagram ve YouTube hesaplarını takip etmektedirler.

\section{Tartışma ve Sonuç}

Dijitalleşmenin bilgi edinme/haberleşme sürecindeki rolüne odaklanan çalışmada, iletişim teknolojileri ve habere erişim süreci ilişkiselliğini Adana Alparslan Türkeş Bilim ve Teknoloji Üniversitesi'nde eğitim gören öğrencilere uygulanan anket ile tespit etmeyi amaçlayan araştırma sonucunda şu veriler elde edilmiştir:

- $\quad$ Öğrencilerin iletişim araçları içerisinde en fazla internet/sosyal medya uygulamalarını kullandığı; internet/sosyal medya uygulamalarını kullanmayan hiçbir öğrencinin olmadığı belirlenmiştir. Bununla birlikte geleneksel medya araçlarının habere erişim sürecinde kullanım oranının düştüğü tespit edilmiştir.

- $\quad$-Sosyal medya araçlarının çoğunlukla iletişim kurmak/görüşme yapmak ve haber elde etmek/bilgilenmek amacıyla kullanıldığı ortaya çıkmıştır. 
- WhatsApp, YouTube ve Instagram uygulamalarını sıkça kullanan katılımcıların önemli bir kısmının günlük 1-2 saat ve 2-3 saat aralığında sosyal medya araçlarında vakit geçirdiği belirlenmiştir.

- Katılımciların büyük bir çoğunluğu habere erişim sürecinde web sitelerini ve sosyal medya uygulamalarını kullanmakta; geleneksel iletişim araçlarını ise haberleşme sürecinde oldukça az tercih etmektedir.

- Anket katılımcılarının habere erişim sürecinde çoğunlukla arama motorlarının yönlendirmesinden faydalandığı, resmi haber/bilgi kaynaklarını kullandığı ve sosyal medya araçlarının yönlendirmesi aracılığı ile habere erişim sağladığı belirlenmiştir.

- Haberlere erişim sürecinde kullanılan iletişim araçlarının tercih edilmesinde; haberlerin/bilgilerin güncel olması, konu ile ilgili ayrıntılı bilgi ve haberlere ulaşılabilmesi, karşılaştırma yapabilme ve farklı kaynaklara erişim imkânının olması, ücretsiz olması gibi faktörler etkili olmaktadır.

- Bireylerin çoğunlukla cep telefonu ve kısmen de bilgisayar aracilı̆g ile habere erişim sürecinde Instagram, WhatsApp, Twitter ve YouTube uygulamalarını sıklıkla kullandıkları ortaya çıkmıştır.

- Habere erişim sürecinde; sürekli güncellenebilir özelliğinin olması, sadece yazı değil, fotoğraf ve video gibi içeriklerin de yer alması, habere anında erişim imkânının bulunması, alternatif haber/bilgi kaynaklarına erişim gibi sebeplerden dolayı çoğunlukla sosyal medya araçları tercih edilmektedir.

- Katılımciların gazetelerin web ortamindaki haber sitelerini kullanarak veya gazetelerin Twitter, Instagram ve YouTube gibi sosyal medya uygulamaların kullanarak/takip ederek gazetelere erişim sağladığı; bayiden gazete satın almayı tercih etmedikleri belirlenmiştir.

Sonuç olarak, dijital yapının gittikçe değiştiği günümüzde, bireylerin habere erişim şeklinin tespit edilmesi, iletişim araçlarının hedef kitlesini gözlemleyebilmesine imkân tanyyacaktır. Bununla birlikte hedef kitlenin yapısina göre zengin içerikler üretilebilecektir. Ayrıca habere erişim sürecinde temel iletişim kaynağı olan sosyal medyanın aktif, nitelikli ve problemsiz bir şekilde kullanılması için yapılması gerekenler de tartışmaya açlacaktır. 


\title{
EXTENDED ABSTRACT
}

\section{Transformation Of News Access Practices: A Field Research On University Students}

\author{
Burak Somuncu - Mustafa Temel \\ Adana Alpaslan Türkeş Science and Technology University, Erciyes University
}

Communication technologies have a structure that significantly affects and transforms the daily life practices of individuals. This tendency of individuals towards digital tools has caused the transformation of individuals' many of the habits and news accessing practices have also changed within this period. Social media applications/tools, the internet in particular, which have become the essential tools of life with their increased usage and structures that allow interaction upon the development of web 2.0 technology, are now actively used in the news accessing process for individuals and within this process, digital media have become the most used tools in accessing information/news.

Studies show that with time, individuals' news accessing practices have changed direction from traditional communication tools to digital tools such as the internet and new media. This study is aimed to determine the transformation of news accessing practices and to define frequently used communication tools in the accessing process. In addition to the studies in the literature, in this study which also focuses on the different uses of digital information channels, individuals' news consumption practices condensing in new media have been analyzed. In this regard, after conducting a theoretical evaluation on the relationality of communication technologies and news accessing process, the findings concerning the survey applied to 200 participants selected by the simple random sampling method among students studying at Adana Alparslan Turkes Science and Technology University are included in the study which focuses on the role of digitalization in the knowledge acquisition/communication process.

In the study, which focuses on the role of digitalization in the knowledge acquisition/communication process, as a result of the research, which aims to 
determine the relationality of communication technologies and news accessing process with the survey applied to the students studying at Adana Alparslan Turkes Science and Technology University, the following data are obtained:

- It has been determined that the students mostly use internet/social media applications among the communication tools and that there are no students who do not use internet/social media applications. On the other hand, it has been determined that the usage rate of traditional media tools has decreased in the news accessing process.

- It has been detected that social media tools are mostly used to communicate/contact and receive news/acquire knowledge.

- It has been determined that a significant portion of the respondents who frequently use WhatsApp, YouTube, and Instagram applications spend 1-2 hours and 2-3 hours per day on social media tools.

- Most of the respondents use websites and social media applications on the news accessing process; and prefer quite less the traditional communication tools in the communication process.

- It has been determined that the survey respondents mostly utilize the routing of search engines, use official news/information sources, and access the news through the routing of social media tools.

- Factors such as the up-to-date news/information, access to detailed information and news on the subject, the opportunity to make comparisons, access to different sources, being free of charge, are effective in choosing the communication tools used in the news accessing process.

- It has been detected that individuals frequently use Instagram, WhatsApp, Twitter, and YouTube applications in the news accessing process mostly via mobile phones and partially via computers.

- Social media tools are mostly preferred in the news accessing process for the reasons such as being continuously updatable, including not only text but also content such as photos and videos, having the opportunity of instant access to news, having access to alternative news/information sources.

- It has been determined that the respondents have access to the newspapers by using the news sites of the newspapers on the web medium or by using/following social media applications such as Twitter, Instagram, and YouTube, and did not prefer to buy newspapers from the newsstand. 
To conclude, in today's world where the digital structure is changing gradually, determining the way individuals' news accessing methods will enable communication tools to observe their target audience. On the other hand, rich content can be produced according to the structure of the target audience. Moreover, the must-do for the active, qualified, and smooth use of social media, the main source of communication in the news accessing process will be also brought up for discussion.

\section{Kaynakça / References}

Balc, Ş., ve Ayhan, B. (2007). Üniversite öğrencilerinin internet kullanım ve doyumları üzerine bir saha araştırması. Selçuk İletişim, 5(1), 174-197.

Bayrak, H. (2019). 2019 Türkiye internet kullantm ve sosyal medya istatistikleri 1.5.2020. tarihinde https://dijilopedi.com/2019-turkiye-internet-kullanim-ve-sosyalmedya-istatistikleri/ adresinden erişilmiştir.

Comscore. (2019). From viral to tribal: The next frontier in publishing. Comscore .

Çakır, H. (2007). Geleneksel gazetecilik karşısında internet gazeteciliği. Erciyes Üniversitesi Sosyal Bilimler Enstitüsü Dergisi, 123-149.

Değirmencioğlu, G. (2016a). Dijitalleşme çağında habercilik pratiklerinin değişimi ve yeni habercilik türleri. Uluslararası Hakemli Illetişim ve Edebiyat Araştırmalarn Dergisi, 10, 45-62.

Değirmencioğlu, G. (2016b). Dijitalleşme çağında gazeteciliğin geleceği ve inovasyon haberciliği. TRT Akademi, 1(2), 590-606.

Eken, M. ve Aydın, H. (2018). Enformasyon toplumunda dini bilgi edinme: İnternet ortamındaki dini enformasyonun güvenilirliği ve kalite kriterleri üzerine bir inceleme. Uluslararası Sosyal Araştrmalar Dergisi, 11(58), 894-906.

Gülnar, B. ve Balc, Ş. (2011). Yeni medya ve kültürleşen toplum. Konya: Literatürk Yayinları.

Güz, N., Yegen, C. ve Yanık, H. (2017). Haber ve bilgi alma aracı olarak yeni medya: Muş İi örneği. International Journal of Social Sciences and Education Research, 3 (4), 1404-1417.

Halıc, N. (2005). Online gazetecilik. Der. S. Alankuş.Yeni Illetişim Teknolojilerive Medya içinde (s. 155-170). İstanbul: IPS İletişim Vakfı Yayınları.

Karaaslan, İ. A. (2018). Online gazeteciliğe geçişte değişen haber tüketim pratikleri: Yetişkinler üzerine bir araştırma. Akdeniz İletişim Dergisi, 241-259.

Karaduman, M. (2003). Haber almada internet kullanım alışkanlıkları. Akdeniz Üniversitesi İletişim Fakültesi Dergisi, 1. 
Karatoprak, Y. (2019). Türkiye'de dijital dönüşümün gazetecilikörgütlenmesi ve pratiklerine yansimasi: Hürriyet ve Medyascope örnekleri. Yayınlanmamış Yüksek Lisans Tezi. İstanbul: Galatasaray Üniversitesi Sosyal Bilimler Enstitüsü.

Kutlu, T. Ö., Bekiroğlu, O. ve Öztürk, Y. (2009). İletişim fakültesi öğrencilerinin haber alma alışkanlıkları: Anadolu Üniversitesi İletişim Bilimleri Fakültesi örneği. Galatasaray Üniversitesi İletişim Dergisi (10), 171-190.

Kürkçü, D. D. (2016). Türkiye'de ulusal ve yerel gazetelerin twitter kullanımı. The Journal of Academic Social Science Studies, 46, 85-101.

Pavlik, J. V. (2013). Yeni medya ve gazetecilik. Ankara: Phoenix Yayınları.

Sucu, İ. (2020). İletişimde yeni medyanın getirdiği değişimler. S Gezgin ve H. Çiftçi (Ed.). Dijital Çă̆da Değişen Gazete ve Gazetecilik, Gazetecilik ve Haber İletişiminde Dönüşüm içinde (s. 39-67). Ankara: İKSAD Yayınevi.

Taşdemir, E. (2015). Yeni medya anlayışıyla habere ulaşmada değişen alışkanlıklar. Yayınlanmamış Yüksek Lisans Tezi. İstanbul: Marmara Üniversitesi Sosyal Bilimler Enstitüsü.

Toruk, İ. (2008). Üniversite gençliğinin medya kullanma alışkanlıkları üzerine bir analiz. Selçuk Üniversitesi Sosyal Bilimler Enstitüsü Dergisi, 19, 475-488.

We are social (t.y.) Mainpage. 20.4.2020 tarihinde https://wearesocial.com/global-digital-report-2019 adresinden erişilmiştir

Yazıcıoğlu, Y. ve Erdoğan, S. (2004). SPSS uygulamalı bilimsel araştırma yöntemleri. Ankara: Detay Yayıncilı.

\section{Kaynakça Bilgisi / Citation Information}

Somuncu, B. ve Temel, M. (2020). Habere erişim pratiklerinin dönüşümü: Üniversite öğrencileri üzerine bir alan araştırması. OPUS-Uluslararası Toplum Araştırmaları Dergisi, 16(31), 4445-4468. DOI: 10.26466/opus.775977 